\title{
Short-term fate of phytodetritus in sediments across the Arabian Sea Oxygen Minimum Zone
}

\author{
J. H. Andersson ${ }^{1, *}$, C. Woulds ${ }^{2}$, M. Schwartz ${ }^{2, * *}$, G. L. Cowie ${ }^{2}$, L. A. Levin ${ }^{3}$, K. Soetaert ${ }^{1}$, and J. J. Middelburg ${ }^{1}$ \\ ${ }^{1}$ Netherlands Institute of Ecology (NIOO-KNAW), Centre for Estuarine and Marine Ecology, POB 140, 4400 AC Yerseke, \\ The Netherlands \\ ${ }^{2}$ University of Edinburgh, School of Geosciences, West Mains Road, EH9 3JW, Scotland \\ ${ }^{3}$ Integrative Oceanography Division, Scripps Institution of Oceanography, La Jolla, CA 92093-0218, USA \\ * now at: Danish Meteorological Institute, Lyngbyvej 100, 2100 Copenhagen, Denmark \\ *** now at: University of West Florida, 11000 University Parkway, Pensacola, FL 32514, USA
}

Received: 23 July 2007 - Published in Biogeosciences Discuss.: 31 July 2007

Revised: 28 November 2007 - Accepted: 14 December 2007 - Published: 24 January 2008

\begin{abstract}
The short-term fate of phytodetritus was investigated across the Pakistan margin of the Arabian Sea at water depths ranging from 140 to $1850 \mathrm{~m}$, encompassing the oxygen minimum zone $(\sim 100-1100 \mathrm{~m})$. Phytodetritus sedimentation events were simulated by adding $\sim 44 \mathrm{mmol}{ }^{13} \mathrm{C}$ labelled algal material per $\mathrm{m}^{2}$ to surface sediments in retrieved cores. Cores were incubated in the dark, at in situ temperature and oxygen concentrations. Overlying waters were sampled periodically, and cores were recovered and sampled (for organisms and sediments) after durations of two and five days. The labelled carbon was subsequently traced into bacterial lipids, foraminiferan and macrofaunal biomass, and dissolved organic and inorganic pools. The majority of the label (20 to $100 \%)$ was in most cases left unprocessed in the sediment at the surface. The largest pool of processed carbon was found to be respiration (0 to $25 \%$ of added carbon), recovered as dissolved inorganic carbon. Both temperature and oxygen were found to influence the rate of respiration. Macrofaunal influence was most pronounced at the lower part of the oxygen minimum zone where it contributed $11 \%$ to the processing of phytodetritus.
\end{abstract}

\section{Introduction}

Phytodetritus arriving in pulses is a major food source for the benthic communities living at ocean margins and deepsea basins (Gooday, 2002). The occurrence of such intense phytodetritus pulses requires episodic production events and a short transit time through the water column where it would otherwise be degraded, i.e. the settling speed needs to be

Correspondence to: J. H. Andersson

(han@dmi.dk) high. Aggregation of phytoplankton into larger particles (Kriest and Evans, 1999) and ballasting (Francois et al., 2002) contribute to high settling speeds. As diatoms easily form aggregates, they are the most important part of phytodetritus settling to the sea floor (Beaulieu, 2002).

Following the fate of naturally occurring phytoplankton blooms and the resulting detritus deposition on the sea floor is logistically difficult due in part to the unpredictable nature of these sedimentation events. Time-series observations of sediment processes (e.g. as total sediment oxygen consumption) have yielded inconclusive results when compared to measured deposition fluxes (Smith, 1992; Sayles et al., 1994; Soetaert et al., 1996). An experimental approach, where algae enriched in ${ }^{13} \mathrm{C}$ are added directly to the sediment surface facilitates the establishment of carbon budgets, whilst it also enables studying several parts of the benthic food web, such as uptake into bacteria, fauna and respiration, simultaneously (Moodley et al., 2002; Witte et al., 2003b; Moodley et al., 2005).

The biogeochemistry of the Arabian Sea is strongly influenced by the two monsoon periods. Periods vary, but the southwest monsoon occurs from late May to early September and the northeast monsoon from December to March (Wiggert et al., 2005). Primary productivity increases dramatically in these two periods due to higher nutrient levels, caused during the southwest-monsoon by coastal upwelling of nutrient-rich waters and during the north-east monsoon by convective mixing together with subsequent advection by large-scale circulation (Naqvi et al., 2002; Kawamiya and Oschlies, 2003). At the end of the algal blooms, detritus sinks through the water column and on to the sea floor (Haake et al., 1993). The sediments of the Arabian Sea therefore receive fluxes of organic material that display strong seasonal variability.

Published by Copernicus Publications on behalf of the European Geosciences Union. 
Table 1. Station characteristics. Temperature and oxygen concentrations taken from CTD casts.

\begin{tabular}{|c|c|c|c|c|}
\hline Depth (m) & $\mathrm{T}\left({ }^{\circ} \mathrm{C}\right)$ & $\mathrm{O}_{2}(\mu \mathrm{M})$ & Latitude & Longitude \\
\hline \multicolumn{5}{|c|}{ Pre-monsoon } \\
\hline 140 & 22 & 92 & $23^{\circ} 17^{\prime} \mathrm{N}$ & $66^{\circ} 43^{\prime} \mathrm{E}$ \\
\hline 300 & 15 & 4.5 & $23^{\circ} 12^{\prime} \mathrm{N}$ & $66^{\circ} 34^{\prime} \mathrm{E}$ \\
\hline 850 & 10 & 5.8 & & \\
\hline 940 & 9.0 & 5.8 & $22^{\circ} 54^{\prime} \mathrm{N}$ & $66^{\circ} 37^{\prime} \mathrm{E}$ \\
\hline 1000 & 8.7 & 6.7 & & \\
\hline 1200 & 7.2 & 15 & $23^{\circ} 0^{\prime} \mathrm{N}$ & $66^{\circ} 25^{\prime} \mathrm{E}$ \\
\hline 1850 & 3.5 & 79 & $22^{\circ} 52^{\prime} \mathrm{N}$ & $66^{\circ} 0^{\prime} \mathrm{E}$ \\
\hline \multicolumn{5}{|c|}{ Post-monsoon } \\
\hline 140 & 18 & 4.9 & $23^{\circ} 17^{\prime} \mathrm{N}$ & $66^{\circ} 43^{\prime} \mathrm{E}$ \\
\hline 300 & 15 & 4.9 & $23^{\circ} 12^{\prime} \mathrm{N}$ & $66^{\circ} 34^{\prime} \mathrm{E}$ \\
\hline 940 & 9.3 & 7.6 & $22^{\circ} 54^{\prime} \mathrm{N}$ & $66^{\circ} 37^{\prime} \mathrm{E}$ \\
\hline 1850 & 3.7 & 76 & $22^{\circ} 52^{\prime} \mathrm{N}$ & $66^{\circ} 0^{\prime} \mathrm{E}$ \\
\hline
\end{tabular}

Another prominent feature of the Arabian Sea is the midwater Oxygen Minimum Zone (OMZ), from a water depth of around $100 \mathrm{~m}$ down to $1100 \mathrm{~m}$, due to respiration of organic matter in combination with input of intermediate waters, with a low oxygen content, from the Southern Hemisphere (Naqvi, 1987; Warren, 1994). The OMZ coincides roughly with maxima in sedimentary organic carbon, suggesting a link between organic carbon preservation and oxygen availability (Cowie et al., 1999).

The short term fate of phytodetritus has been studied at several places in the ocean (Blair et al., 1996; Moodley et al., 2000, 2002; Witte et al., 2003b), but no study has yet directly compared sites in suboxic and oxic environments. At present low-oxygen environments are only a minor part of the world ocean (Helly and Levin, 2004), but are biogeochemically important for a number of processes such as organic carbon preservation (Hartnett et al., 1998; Burdige, 2007), metal cycling (Aller, 1994), removal of biologically available nitrogen through denitrification and natural production of $\mathrm{N}_{2} \mathrm{O}$, contributing to global warming (Naqvi et al., 2000). It is also important to note, that the area of oxygen-poor waters is likely to expand due to global warming, both as a direct effect of decreased solubility and indirectly because of enhanced stratification (Keeling and Garcia, 2002).

In this paper we present results from an experimental study on the short-term fate of phytodetritus on the sea floor, at sites spanning the OMZ on the Pakistan margin of the Arabian Sea, before and after the SW monsoon. Phytodetritus sedimentation events were simulated by adding a known amount of ${ }^{13} \mathrm{C}$ labelled diatoms and subsequently tracing the ${ }^{13} \mathrm{C}$ into bacteria, via incorporation into phospholipid-derived fatty acids (PLFAs) specific to bacteria, into foraminifera and macrofauna, and into dissolved organic and inorganic carbon pools. Site depths ranged from 140 to $1850 \mathrm{~m}$, which encompass the $\mathrm{OMZ}$ and provided us with a natural laboratory where the effect of oxygen and temperature could be tested under natural conditions.

\section{Material and methods}

\subsection{Study site}

Experiments were conducted on cruises CD146 and CD151, before and immediately after the summer monsoon of 2003 on-board RRS Charles Darwin. Thus it was possible to assess changes in benthic community response associated with the biannual monsoon-driven delivery of OM to the sediment. Experiments were conducted at sites along an offshore transect off the Indus River, across the Pakistan margin of the Arabian Sea (Table 1).

\subsection{Experimental conditions}

Cores (i.d. $10 \mathrm{~cm}$ ) were taken using a multiple-barrel "megacorer", providing virtually undisturbed samples (Barnett et al., 1984), and immediately transferred to a temperature controlled laboratory set to in situ temperature, where the experiments were conducted.

For the purpose of incubation experiments, cores were fitted with core top seals, and all air bubbles were excluded. The undersides of the seals featured magnetic stir bars, ports for oxygen and temperature microsensors, and a further five ports; one for slurry introduction, two to allow water sampling, and two for the "oxystat" system. The "oxystat" system was designed to maintain core-top oxygen levels at seafloor conditions despite sediment oxygen consumption. On each core the two oxystat ports were connected to each other via $8 \mathrm{~m}$ gas-permeable tubing (the oxystat gill), submerged in a reservoir of filtered seawater (the oxystat reservoir). This reservoir was sparged with an air and nitrogen mix tuned to maintain oxygen levels slightly above those at the seafloor. A peristaltic pump circulated core top water out of each core barrel, through its dedicated oxystat gill, and back. Diffusion across the tubing in the reservoir replenished core top water with dissolved oxygen which had been consumed. Sub-aerial parts of the oxystat system were made of gas impermeable tubing.

Diatoms grown in a ${ }^{13} \mathrm{C}$ enriched medium were freeze dried onto silica or kaolin ballast and injected into the barrels, as a slurry dissolved in purified water, through a port in the core lid. The labelled diatoms consisted of $75 \%{ }^{13} \mathrm{C}$, except at the $1850 \mathrm{~m}$ station in the post-monsoon season, where a different batch of algae was used consisting of $31 \%{ }^{13} \mathrm{C}$. This resulted in a loading of between 3.6 and $5.8 \mathrm{mg}$ of ${ }^{13} \mathrm{C}$ added to each core $\left(43.9 \pm 6.8 \mathrm{mmol}^{13} \mathrm{C} \mathrm{m}^{-2}\right)$.

Each experiment was conducted simultaneously on two replicate cores, and incubated in the dark for 2 or 5 days, exact durations varied slightly due to logistical constraints. All cores were incubated with a gentle stirring of the overlying water. Samples of the overlying water were taken at 
the beginning and end of, and at pre-determined intervals, during each experiment. The samples were immediately poisoned with $50 \mu \mathrm{L}$ of a saturated solution of $\mathrm{HgCl}_{2}$ to vials with volumes of $5 \mathrm{~mL}$, in order to prevent further microbial activity. After termination of each experiment, cores were sectioned at $0.5 \mathrm{~cm}$ intervals to $2 \mathrm{~cm}$ depth, then at $1 \mathrm{~cm}$ intervals to $10 \mathrm{~cm}$ depth, and then at $2 \mathrm{~cm}$ intervals to $20 \mathrm{~cm}$ depth. One half of each slice was placed in a centrifuge tube for porewater extraction, and the other half was placed in a petri dish for faunal sampling. After centrifugation, the supernatant was transferred to vials for subsequent $\delta^{13} \mathrm{C}-\mathrm{DOC}$ and $\delta^{13} \mathrm{C}$-DIC analysis (see below). The remaining sediment, used for the analysis of $\delta^{13} \mathrm{C}-\mathrm{POC}$ and bacterial lipids, were transferred to plastic bags and freeze dried. Fauna samples were sieved using filtered sea water, and residues from $300 \mu \mathrm{m}, 150 \mu \mathrm{m}$ and $63 \mu \mathrm{m}$ sieves were retained. From the $300 \mu \mathrm{m}$ and some $150 \mu \mathrm{m}$ residues all fauna were extracted by sorting at $12-20 \mathrm{X}$ magnification to the lowest possible taxonomic level, and frozen in pre-weighed tin capsules or combusted glass vials.

In addition to the shipboard incubations, labelling experiments were also conducted in situ using a benthic chamber lander (Elinor). The lander system has been described in detail by Glud et al. (1995). On arrival at the sea floor the lander inserted a $30 \times 30 \mathrm{~cm}$ chamber into the underlying sediment. Pre-programmed syringes, a stirring motor, an oxygen electrode and an external oxystat gill allowed maintenance of ambient oxygen levels, slurry introduction, sample withdrawal and stirring comparable to the shipboard experiments. In these experiments, $19-27 \mathrm{mg}{ }^{13} \mathrm{C}$ was added, giving a dose of $18-25 \mathrm{mmol}^{13} \mathrm{C} \mathrm{m}^{-2}$. After a 2-day incubation a shovel closed the bottom of the chamber, weights were dropped and the lander ascended to the surface. Sediment from the lander chamber was sub-sampled using two short megacore tubes. These cores were sectioned and the samples were processed as described above.

\subsection{Analytical methods}

\subsubsection{Sediments and fauna}

Aliquots of $200-400 \mu \mathrm{gC}$ of gently disaggregated freezedried sediment were weighed into silver capsules. Decarbonation was achieved by carefully adding 2-5 drops of double distilled $6 \mathrm{M} \mathrm{HCl}$. Samples were dried overnight at $60^{\circ} \mathrm{C}$ and stored in a vacuum desiccator prior to analysis.

Faunal samples were air dried at $45^{\circ} \mathrm{C}$ and stored in a vacuum desiccator. Soft bodied fauna were de-carbonated in two layers of tin capsule using 2-5 drops of $1 \mathrm{M} \mathrm{HCl}$, followed by drying at $40^{\circ} \mathrm{C}$. Macrofauna and Foraminifera were de-carbonated with $6 \mathrm{M} \mathrm{HCl}$, the original tin capsule having been placed inside silver capsules. All samples were analysed on a dedicated Europa Scientific (Crew, UK) Tracermass isotope ratio mass spectrometer with a Roboprep Dumas combustion sample converter.

\subsubsection{Bacteria}

Bacterial biomass and uptake were quantified by measuring the concentration and isotopic composition of three PLFAs, iC14:0, iC15:0 and aiC15:0 specific to bacteria, following Middelburg et al. (2000).

PLFAs were extracted from $4 \mathrm{~g}$ freeze-dried sediment using a modified Bligh and Dyer extraction (Boschker et al., 1999). The lipid extract was fractionated on silicic acid into different polarity classes by sequential elution with chloroform, acetone and methanol. The methanol fraction containing the PLFAs was derivatised to yield fatty acid methyl esters (FAMEs).

The isotopic composition and concentrations were determined using a Varian 3400 gas chromatograph equipped with a HP5 column, coupled via a combustion interface to a Finnigan Delta+ isotope ratio mass spectrometer (IRMS).

\subsubsection{Dissolved inorganic/organic carbon}

Samples for the determination of dissolved inorganic and organic carbon were stored refrigerated in darkness and upsidedown in head-space vials. The vials were sealed with butyl rubber membranes covered with Teflon to prevent gas diffusion through the membrane. Concentrations of dissolved inorganic carbon were measured by coulometric titration. Isotopic compositions were measured independently by injecting head-space gas directly in a continuous stream of helium into a Finnigan Delta+ IRMS via a ConFloII interface following Moodley et al. (2000).

Concentrations and isotopic composition of dissolved organic carbon (DOC) were measured on the same samples used for the determination of $\delta^{13} \mathrm{C}$-DIC. Dissolved inorganic carbon was removed by adding sulphuric acid in excess and subsequent stripping with helium. The samples were analysed with a Skalar Formacs ${ }^{\mathrm{LT}}$ TOC analyser coupled through a ConFloII interface to a Finnigan Delta S IRMS. The calibration standards were prepared with potassium phtalate dissolved in purified water (MilliQ).

\subsection{Data treatment}

Incorporation of ${ }^{13} \mathrm{C}$ is reflected as excess (above background) ${ }^{13} \mathrm{C}$ and is expressed in terms of total uptake in millimoles of ${ }^{13} \mathrm{C}$ per square meter as well as specific uptake (i.e. $\Delta \delta^{13} \mathrm{C}=\delta^{13} \mathrm{C}_{\text {sample }}-\delta^{13} \mathrm{C}_{\text {control }}$, where $\delta^{13} \mathrm{C}$ is expressed relative to Vienna Pee Dee Belemnite (VPDB)). Total uptake was calculated as the product of excess ${ }^{13} \mathrm{C}(E)$ and carbon concentrations. Excess ${ }^{13} \mathrm{C}$ is the difference between the fraction ${ }^{13} \mathrm{C}$ of the control $\left(F_{\text {control }}\right)$ and the sample $\left(F_{\text {sample }}\right): E=F_{\text {sample }}-F_{\text {control }}$, where the fraction of ${ }^{13} \mathrm{C}$ $(F)$ was calculated from the ratio $(R)$ of ${ }^{13} C /{ }^{12} C$,

$F={ }^{13} C /\left({ }^{13} C+{ }^{12} C\right)=R /(R+1)$. 

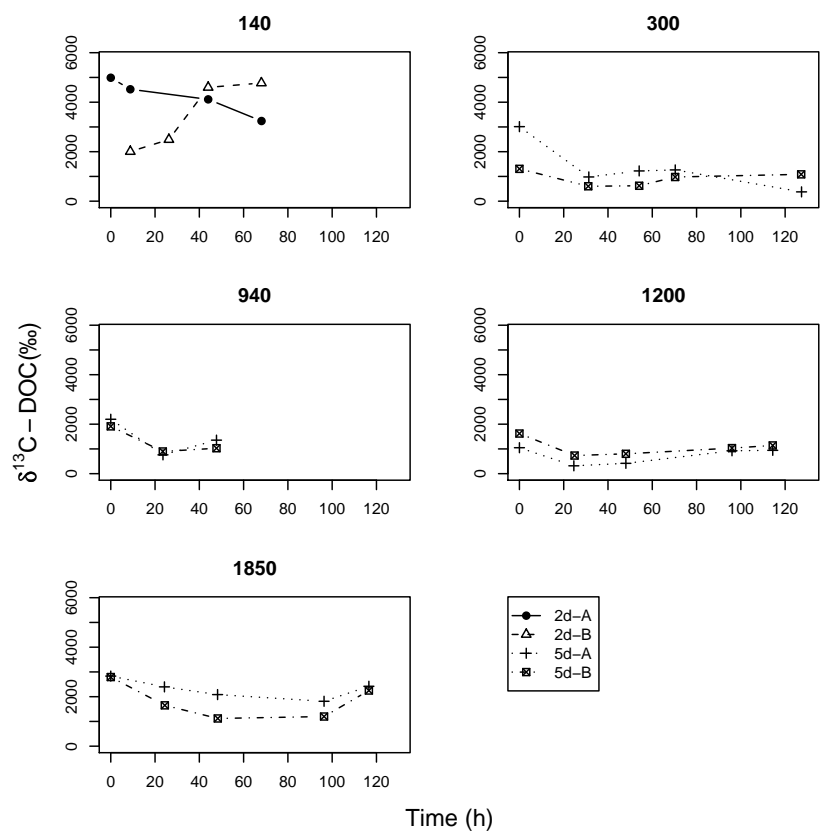

Fig. 1. Isotopic composition of dissolved organic carbon in the overlying water from the pre-monsoon cruise. A, B indicate replicate cores.

The carbon isotope ratio $(R)$ was derived from the measured $\delta^{13} \mathrm{C}$ values as:

$R=\left(\delta^{13} C / 1000+1\right) \cdot R_{\mathrm{VPDB}}$,

where $R_{\mathrm{VPDB}}=0.0112372$.

Incorporation into bacterial biomass was calculated in the following way,

$I_{\text {bact }}=\frac{\sum_{i=1}^{3} I_{\mathrm{PLFA}, i}}{F_{\mathrm{PLFA}} \cdot C_{\mathrm{PLFA}}}$

where $F_{\mathrm{PLFA}}=0.12$ is the fraction of the three PLFA's to total bacterial PLFA's (Moodley et al., 2005) and $C_{\text {PLFA }}=0.038$ is the fraction of PLFA carbon to total bacterial carbon (Boschker and Middelburg, 2002).

\section{Results}

The oxystat system designed to maintain the oxygen concentration on the shipboard incubations, regulated the oxygen concentrations to within $10 \%$ of in-situ values.

The $\delta^{13} \mathrm{C}-\mathrm{DOC}$ values in overlying waters were elevated well above background values $(-20 \pm 1 \%$, assuming that natural sedimentary DOC has a similar isotopic composition to that of POC in underlying sediments) at the start of all incubations (Fig. 1), indicating that the added phytodetritus was a source of some DOC as well as POC. The $\delta^{13} \mathrm{C}-\mathrm{DOC}$ values decreased over time as a result of dilution with unlabeled DOC present in the porewater. In several cases the
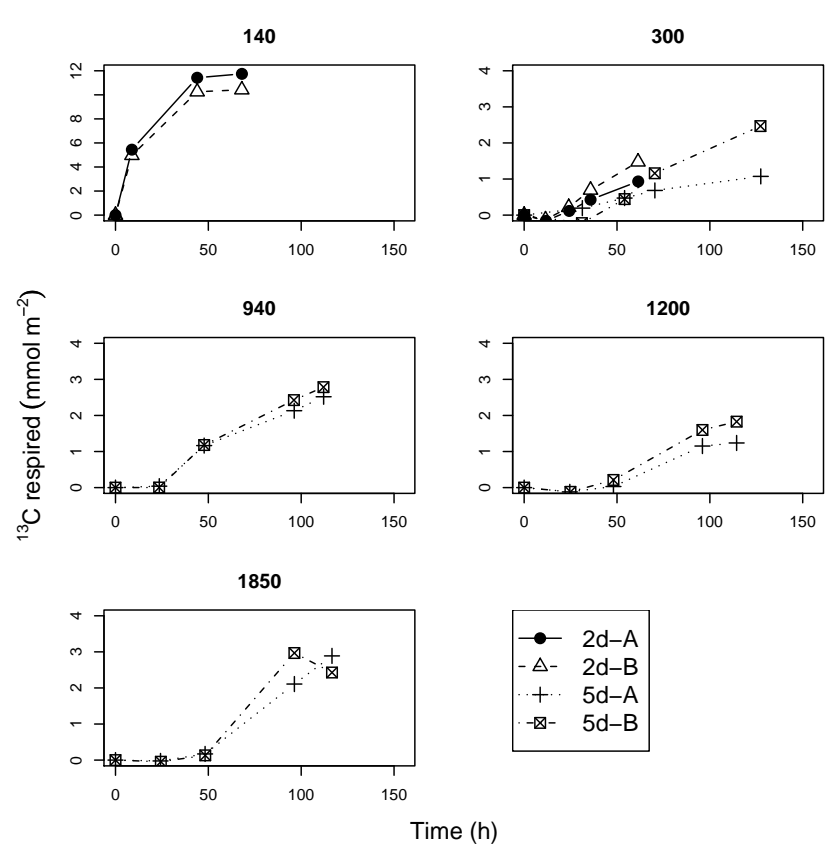

Fig. 2. Respiration of the added tracer during the pre-monsoon cruise. Note the different scale for station 140. See Table 1 for details about the stations. A, B indicate replicate cores.

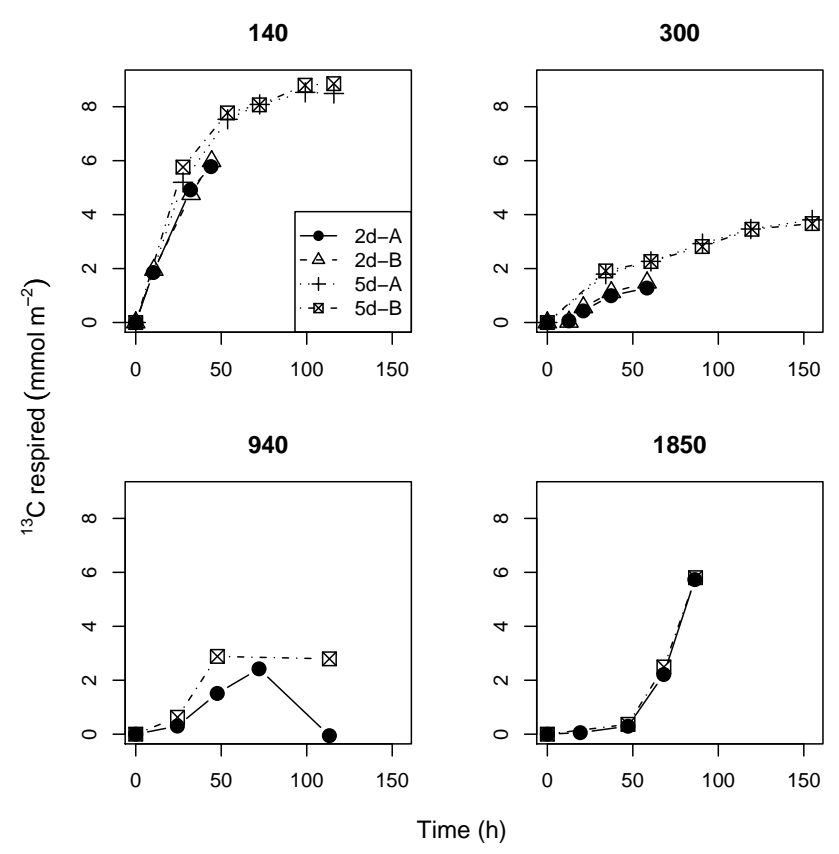

Fig. 3. Respiration of the added tracer during the post-monsoon cruise. See Table 1 for details about the stations. A, B indicate replicate cores.

$\delta^{13} \mathrm{C}$-DOC increased again after the initial decrease as a result of degradation of labelled POC. 


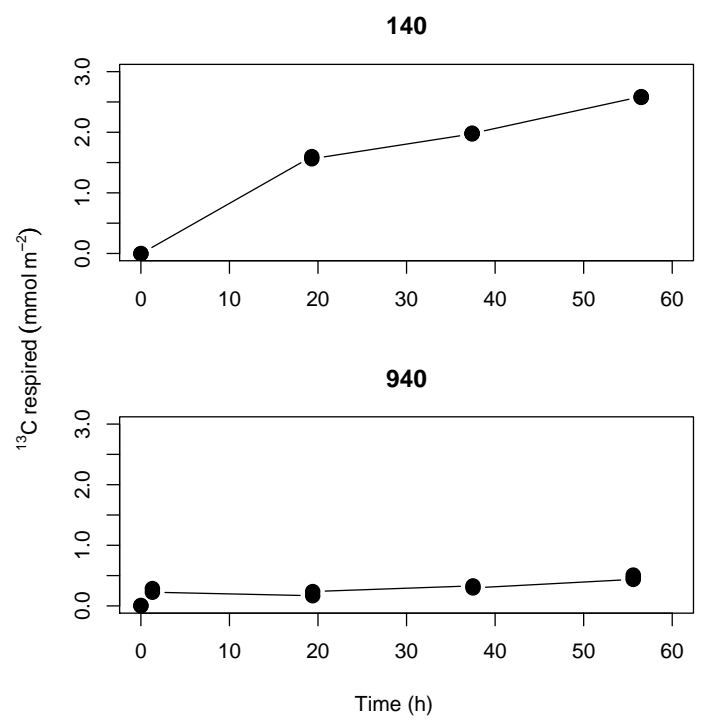

Fig. 4. Respiration of the added tracer during the post-monsoon cruise in in situ incubations. See Table 1 for details about the stations.

As the overlying water was sampled for $\delta^{13} \mathrm{C}-\mathrm{DIC}$ and DIC at several times during the incubations, it was possible to investigate the extent and timing of respiration more closely than components such as faunal and bacterial uptake, which were sampled only at the end of the 2- and 5-day incubations. The evolution of excess ${ }^{13} \mathrm{C}$ in DIC over time was in general very comparable between replicate cores although these were collected purposely from different casts. The most intense respiration was found at the shallowest station, at $140 \mathrm{~m}$. This is also the station where respiration of the added phytodetritus was evident already from the start of the incubation (Fig. 2 and 3). Later, however the respiration rate slowed down. The fast initial response followed by gradual slowing down and an apparent eventual halt is found in both the pre- and post-monsoon data at the $140 \mathrm{~m}$ station. Respiration of added phytodetritus at $300 \mathrm{~m}$ in the OMZ also started immediately, but with a much lower rate. In contrast, respiration at the deeper stations all showed an initial lag phase with very low rates of respiration but a marked increase after this phase. Overall, the length of the lag phase increased with increasing water depth; about one day at station 940 increasing to about two days at the $1200 \mathrm{~m}$ and $1850 \mathrm{~m}$ stations (Fig. 2).

Due to technical difficulties with the lander, the number of successful in situ deployments was limited. However, respiration of added algal material was evident at both the $140 \mathrm{~m}$ and $940 \mathrm{~m}$ stations with relative differences in rates similar to those observed in the shipboard incubations (Fig. 4).

Downcore profiles of sediment $\delta^{13} \mathrm{C}-\mathrm{POC}$, obtained at the end of the experiments show limited downward mixing of the added algae (Fig. 5) in both 2- and 5-day incubations. Moreover, there was no apparent change over time. Despite
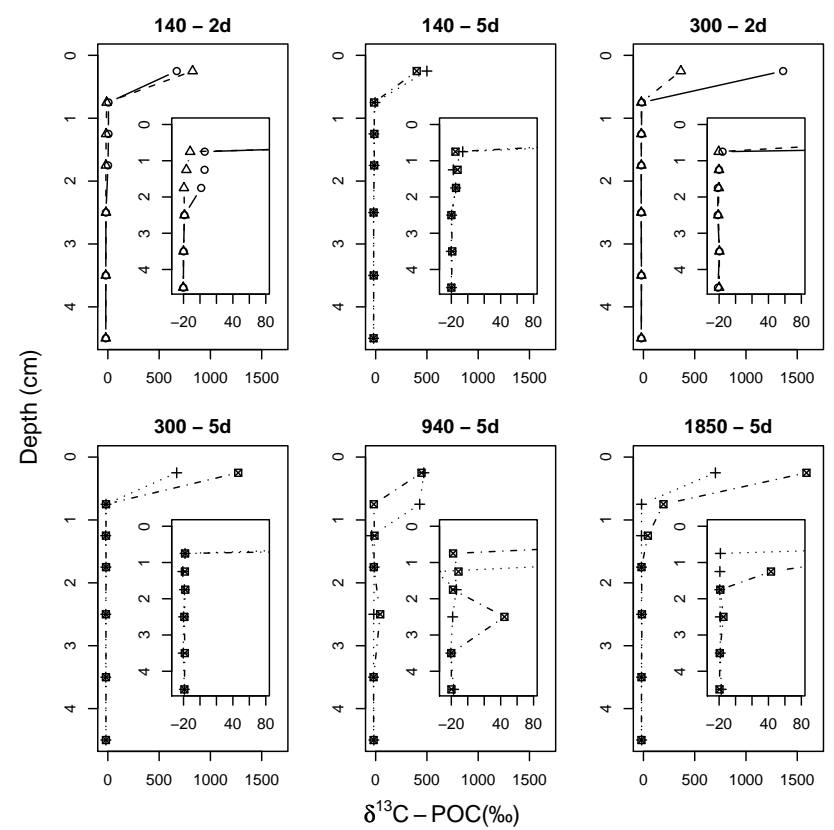

Fig. 5. Excess $\delta^{13} \mathrm{C}-\mathrm{POC}$ from the post-monsoon cruise. Insets zoom in on a limited range in delta values to allow distinguishing small differences between stations with limited and no vertical displacement of added algal ${ }^{13} \mathrm{C}$.

the limited vertical displacement, small amounts of labelled material were brought down from the surface to deeper layers at all stations except in the core of the OMZ (300 m station) where all the added phytodetritus remained in the topmost sediment layer $(0-0.5 \mathrm{~cm})$.

The $\delta^{13} \mathrm{C}$-DIC of pore-waters was highly enriched relative to background values. Enrichment was highest in the top centimeters, exponentially decreasing with depth in the sediment (Fig. 6). Except for one profile from $140 \mathrm{~m}$ in the premonsoon cruise exhibiting sub-surface peaks, all porewater profiles appear to be the combined result of respiration at the sediment-surface and downward diffusion into the sediment.

Transfer of ${ }^{13} \mathrm{C}$ from phytodetritus to bacteria was highest in the upper two centimeters (Fig. 7). Label assimilation in bacteria was also detectable in the $2-5 \mathrm{~cm}$ depth layer, but contributed $<1 \%$ to the depth-integrated bacterial uptake. The labelling pattern of the three bacteria-specific fatty acids, iC14:0, iC15:0 and aiC15:0 was consistent across stations and depth layers in the sediment. The fatty acid with the highest specific uptake $\left(\Delta \delta^{13} \mathrm{C}\right)$ in general is iC15:0. Bacterial uptake was quite similar across the stations above $1000 \mathrm{~m}$ depth. Uptake was much lower at greater station depths, even after five days (Table 2). Bacterial uptake of the added algal carbon was on average comparable to macrofaunal and foraminiferal uptake (Woulds et al., 2007). At the $300 \mathrm{~m}$ station, where exceptionally low oxygen levels resulted in a near-total absence of macrofauna, bacterial and foraminiferal 

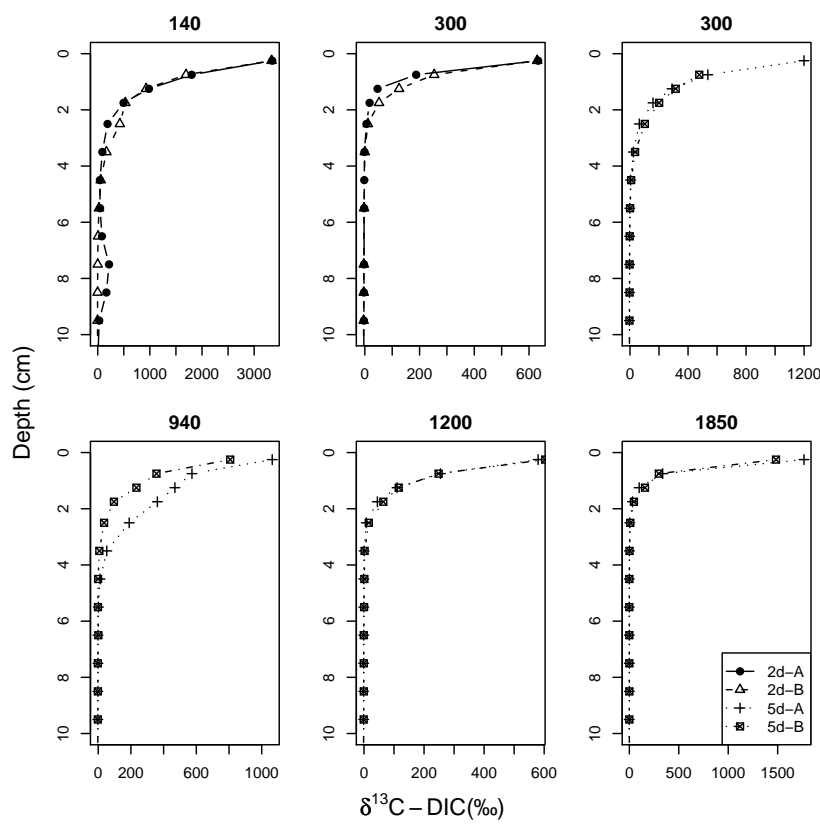

Fig. 6. Isotopic composition of the porewater DIC at the end of the experiments at five different water depths from the pre-monsoon cruise. Results are shown for a maximum depth of $10 \mathrm{~cm}$, although samples were analysed to a depth of $20 \mathrm{~cm}$. A, B indicate replicate cores.

uptake was similar. At the $940 \mathrm{~m}$ station, the macrofauna was much more prominent and dominated the carbon processing.

Respiration was measured in incubations lasting both 2 and 5 days. To allow the comparison of all incubations, all respiration values were linearly interpolated from the two closest sampling times to a common time of $44 \mathrm{~h}$ (Fig. 8). As some incubations nominally lasting 5 days had to be terminated earlier due to limited processing manpower, these were interpolated to $86 \mathrm{~h}$ (Fig. 9). Respiration after $44 \mathrm{~h}$ was most intense at the shallowest station and decreased with station depth. However, after $86 \mathrm{~h}$ the decrease with station depth is only evident at the 140 to $300 \mathrm{~m}$ stations. Note that a different batch of algae was used for the $1850 \mathrm{~m}$ station in the post-monsoon cruise, which apparently was more easily mineralised.

\section{Discussion}

\subsection{Experimental approach}

Potential artifacts in shipboard incubations of oceanic sediments have been reported repeatedly (e.g. Glud et al., 1994) and include possible changes due to decompression or warming of the sediment during retrieval and incubation of the cores. At most stations, we also performed in situ incubations to be able to verify the shipboard results. However, the
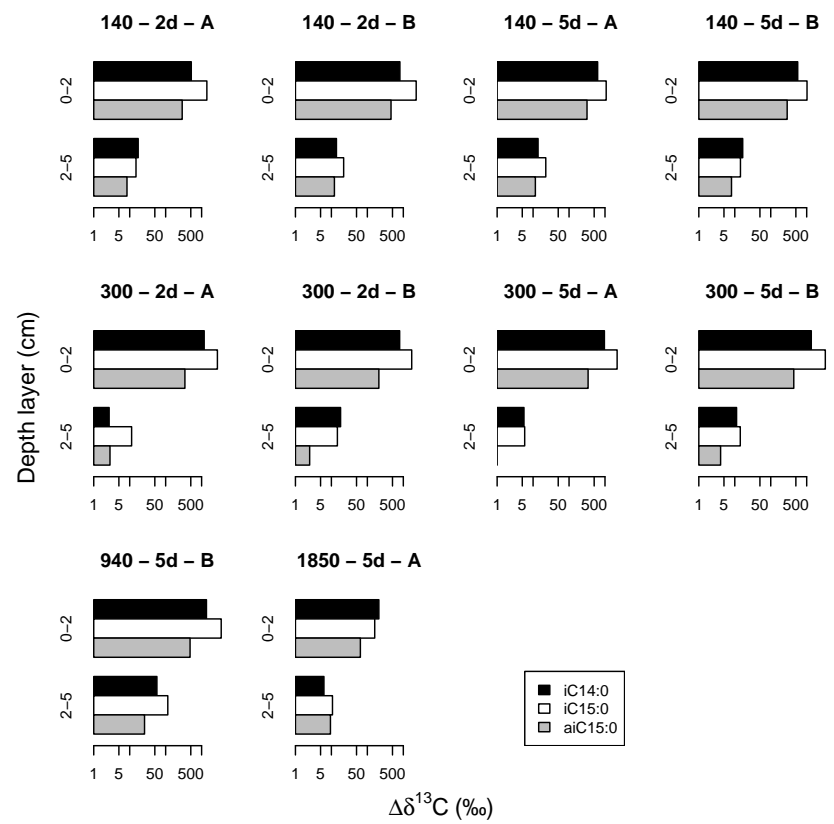

Fig. 7. Specific uptake of ${ }^{13} \mathrm{C}$ into bacterial fatty acids in two depth layers at all stations during the post-monsoon cruise. A, B indicate replicate cores. Note the use of a logarithmic X-axis.

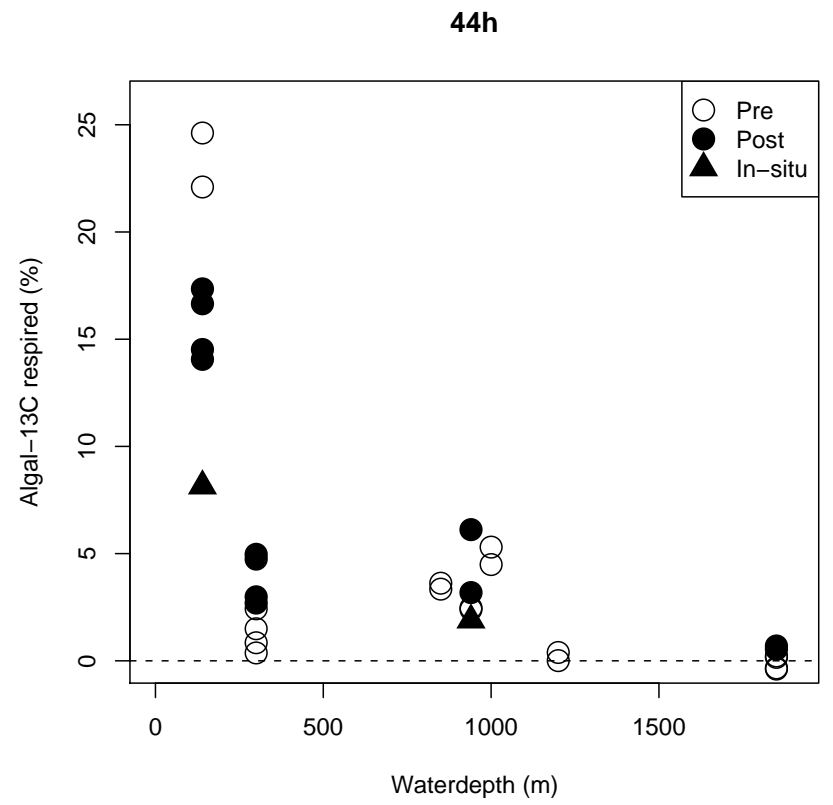

Fig. 8. Interpolated percentage of total label respired after $44 \mathrm{~h}$ across the ocean margin. A different batch of algae was used for station 1850 during the post-monsoon cruise. All shipboard experiments were performed in duplicate.

distribution of added phytodetritus in the in situ incubation chamber was very patchy, as highlighted by large differences 
Table 2. Mean (and standard deviations) of phytodetrital processing rates in mmol ${ }^{13} \mathrm{C} \mathrm{m}^{-2}$ and recovery in $\%$ of the added carbon. Recovery is calculated as the sum of macrofaunal uptake, respired carbon and bulk excess POC, as POC already includes the contribution from both bacteria and foraminifera. Contribution from macrofauna and foraminifera were taken from Woulds et al. (2007). The absolute amount of algae added to in situ incubations were higher than in the shipboard incubations, but lower on a per area basis.

\begin{tabular}{llllllll}
\hline Station & Days & POC & Bacteria & Foraminifera & Macrofauna & Respired & Recovery \\
\hline \multicolumn{2}{l}{ Pre-monsoon } & & & & & & \\
140 & 2 & $24.1(10.1)$ & $1.26(0.2)$ & 0.38 & 2.61 & $11.1(0.936)$ & $81.6(23.9)$ \\
300 & 2 & $16(0.854)$ & $0.27(0.03)$ & 0.31 & 0 & $1.2(0.383)$ & $44(3.47)$ \\
300 & 5 & 24.4 & $0.41(0.15)$ & 0.38 & 0 & $1.77(0.986)$ & 61.6 \\
850 & 2 & & $0.18(0.05)$ & & & \\
940 & 5 & 8.34 & $0.26(0.21)$ & 0.08 & 3.00 & $2.65(0.188)$ & 35.0 \\
1000 & 2 & & $0.17(0.03)$ & & & & \\
1200 & 5 & $10.2(2.18)$ & $0.05(0)$ & 0.41 & 0.17 & $1.53(0.418)$ & $29.7(6.76)$ \\
1850 & 5 & $48.2(15.5)$ & $0.14(0.08)$ & 0.37 & 0.068 & $2.66(0.326)$ & $84.6(27.7)$ \\
\hline Post-monsoon & & & & & \\
140 & 2 & $32.9(3.22)$ & $1.71(0.815)$ & 1.17 & 0.587 & $5.88(0.139)$ & $96(8.52)$ \\
140 & 5 & $18.6(2.64)$ & $1.6(0.509)$ & 2.19 & 0.605 & $8.67(0.258)$ & $69.3(6.53)$ \\
140 & 2 (in situ) & $0.5(0.42)$ & $0.29(0.24)$ & 0.628 & 0.489 & 2.58 & 72.0 \\
300 & 2 & $33(25.3)$ & $1.93(1.33)$ & 0.321 & 0 & $1.38(0.141)$ & $84.8(63)$ \\
300 & 5 & $36.2(15.8)$ & $2.79(1.36)$ & 1.30 & 0 & $3.74(0.0973)$ & $96.8(38.6)$ \\
940 & 5 & $31.9(4.48)$ & $0.95(1.34)$ & 0.0677 & 4.38 & $2.61(0.261)$ & $94.1(11.9)$ \\
940 & 2 (in situ) & $0.11(0.01)$ & $0.07(0.01)$ & 0.039 & 2.96 & 0.46 & 36.0 \\
1850 & 5 & $32.7(21.6)$ & 0.08 & 0.228 & 0.0984 & $5.77(0.0493)$ & $78.4(44)$ \\
\hline
\end{tabular}

in excess ${ }^{13} \mathrm{C}$-POC and bacterial uptake between subcores (Table 2) at the $140 \mathrm{~m}$ site. As a consequence of patchy availability of phytodetritus, a large fraction of bacteria residing at the sediment surface was unable to participate in the processing of this material. Upscaling measurements made on small subcores, such as excess ${ }^{13} \mathrm{C}-\mathrm{POC}$ and bacterial uptake rates, introduces large uncertainty in total chamber estimates.

Incubation of sediments from low-oxygen environments poses a major challenge because measures should be taken to maintain oxygen levels close to ambient. Therefore, water from each core was pumped through gas-permeable silicon tubing placed in a reservoir where oxygen concentrations were kept at in situ concentrations. This ensured ambient oxygen levels and thus a close-to-natural functioning of the benthic community. However, since the partial pressure of carbon dioxide was higher in the cores compared to the controlled reservoir, it is possible that carbon dioxide effluxed from the experimental cores and consequently that absolute values of respiration are underestimated.

While core incubations are able to replicate both the temperature and oxygen conditions of the in situ environment, the stirring rate is constant and is set to prevent resuspension. Should resuspension occur in the natural environment, it could alter the fate of phytodetritus by keeping it exposed longer to decomposition in the benthic boundary layer (Beaulieu, 2003).

The natural status of phytodetritus arriving at the seafloor has been found to be highly variable in terms of degradation

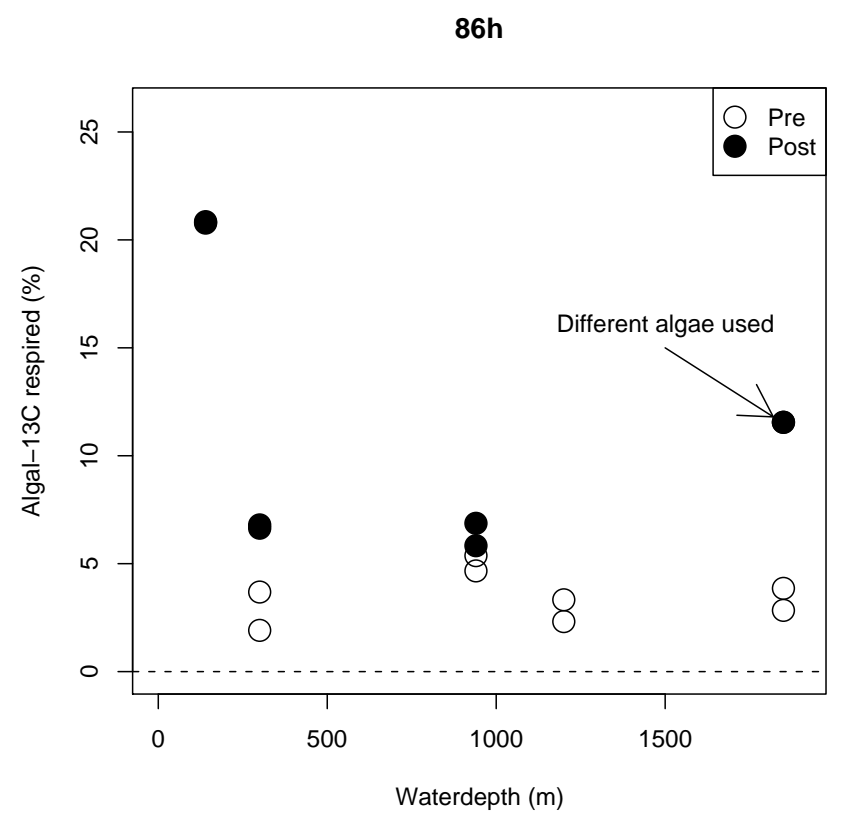

Fig. 9. Interpolated percentage of total label respired after $86 \mathrm{~h}$ across the ocean margin. A different batch of algae was used for station 1850 at the post-monsoon cruise, which apparently was more easily mineralised. All experiments were performed in duplicate.

state and composition, and it is thus not easy to select the appropriate pre-treatment of experimental phytodetritus such 
that it resembles natural conditions best (Beaulieu, 2002). Similarly, it was not possible to select proportionally representative amounts of labeled $\mathrm{C}$ to add to the different sites. Instead, we chose to add the same material and the same quantity to all sediments, allowing a direct comparison among sites. Adding the same amount of phytodetritus at all depths does not simulate natural inputs, as these would generally be lower at greater depths due to respiration within the water column (Andersson et al., 2004). Our experiments were therefore designed to directly compare the relative potential for phytodetritus processing at different study sites. However, it has been shown that degradation of particulate organic material is slowed down in suboxic water columns such as the one found in the Arabian Sea (Devol and Hartnett, 2001). Thus, in OMZ areas, the flux of organic material arriving at the seafloor is of a more similar magnitude at different depths, than it would be for an entirely oxic water column.

That the nature of reactive organic matter added may be important to experimental results was possibly demonstrated in the response recorded during the post-monsoon period at the $1850 \mathrm{~m}$ station. Due to problems with algal cultures, a different batch of labeled diatoms was used, which apparently was much more readily respired. Moreover, the immediate ${ }^{13} \mathrm{C}$ enrichment of DOC in incubations at all stations (Fig. 1) indicates that DOC was added with the freezedried algal material despite thorough rinsing procedures. Although this unintended addition of 13C-DOC amounted to less than $5 \%$ of total added ${ }^{13} \mathrm{C}$ in all cases, the combined results highlight that benthic carbon processing studies using artificially introduced phytodetritus are not necessarily comparable, because the results may depend on the type of algae used, their preconditioning and the specific carbon loading (Buhring et al., 2006).

Summing up the contribution from all the compartments, i.e. uptake into bacteria, foraminifera, macrofauna, respiration and unprocessed algal carbon remaining in the sediment a recovery can be calculated. POC measurement includes the contribution from both unprocessed algal carbon and carbon taken up by bacteria and foraminifera (macrofauna was picked out). Thus, the recovery was calculated by the sum of the POC pool, the uptake into macrofauna and the DIC pool. The recovery was high in most of the experiments from the post-monsoon cruises and some of the pre-monsoon stations (Table 2). Apparent label losses are primarily due to uncertainty in the measurement of excess ${ }^{13} \mathrm{C}$-POC. Another potential loss of ${ }^{13} \mathrm{C}$-DIC was losses of gaseous ${ }^{13} \mathrm{C}-\mathrm{CO}_{2}$ through the silicon tubing (see above).

\subsection{Fate of phytodetritus}

Our results clearly show that, within 2-to-5 day timescales, a minor fraction of total added carbon was processed at all sites, and the fate of the majority of the processed carbon was respiration, in both pre- and post-monsoon seasons. The no- table exception was at the $940 \mathrm{~m}$ station where in both preand post-monsoon seasons, uptake by the abundant macrofauna dominated the phytodetritus processing. The occurrence of the amphinomid polychaete Linopherus sp. at this station accounted for most of the macrofaunal uptake and influenced the entire carbon processing (Woulds et al., 2007). When present, animals such as these amphinomid polychaete have a large impact on the mineralisation pathway, by subducting organic matter below the oxic zone (Levin et al., 1997). This demonstrates that short-term carbon cycling pathways can differ dramatically, with possible consequences for the fate of carbon (e.g. burial vs respiration).

At the $140 \mathrm{~m}$ site there was a marked shift in the uptake patterns from pre- to post-monsoon due to an upward shift in the upper boundary of the OMZ, which caused bottom waters to become considerably less oxygenated (Table 1). Concurrent with this decrease in oxygen, the uptake shifted from macrofauna-dominated to more equally divided between bacteria, foraminifera and macrofauna. The shift in uptake pattern indicates that changes in oxygen, from fully oxygenated to hypoxic conditions, has a major impact on the pathway of benthic phytodetritus processing (Woulds et al., 2007). Respiration also responded to the shift in oxygen concentration, but in a less dramatic sense.

Specific uptake into bacterial lipids expressed as $\Delta \delta^{13} \mathrm{C}$ in the $0-2 \mathrm{~cm}$ layer was always less than $3500 \%$. Using Eqs. (1) and (2) this corresponds to a fraction of ${ }^{13} \mathrm{C}$ of $4.8 \%$. Thus, even the most active of the bacterial lipids did not experience more than 5\% turnover during five days of incubation. The turnover calculation assumes an equal contribution of all bacteria in the $0-2 \mathrm{~cm}$ layer.

Transfer of labeled carbon below the surface layer was limited, even at stations where macrofauna was present. Even though the impact of fauna might be less than that found elsewhere (Witte et al., 2003a; Kamp and Witte, 2005), the fauna left a clear imprint at station 940 in the profiles of $\delta^{13} \mathrm{C}-\mathrm{POC}$, bacterial lipids and in the porewater profiles of $\delta^{13} \mathrm{C}$-DIC (Figs. 5, 7, 6), where the penetration of label was deeper and values were more variable.

\subsection{Factors governing respiration}

The importance of benthic respiration as a fate for phytodetritus on the timescale of days to months is still largely unknown and results reported from the literature are ambiguous. Moodley et al. (2002) examined the fate of phytodetritus in a deep-sea environment (NE Atlantic, $2170 \mathrm{~m}$ ) on a relatively short timescale, by incubating sediment amended with labelled algae for $35 \mathrm{~h}$. They found that $1.5 \%$ of the added algae were respired during these $35 \mathrm{~h}$. However, $40 \%$ of the algal carbon was left unaccounted for after the experiment, implying that it might have been lost prior to injection. Assuming that this was the case the respiration would increase to $2.4 \%$. Moodley et al. (2005) later repeated this experiment at several locations, with a large range in water depths 
and temperatures, and found that $\sim 15 \%$ of the added algal carbon was respired at all locations after $24 \mathrm{~h}$. Similarly, in our study, respiration accounted for up to $25 \%$ of the added algae within 5 days at the $140 \mathrm{~m}$ station. It was the dominant fate of the processed phytodetritus. This result is similar to the study of Moodley et al. (2005) where respiration dominated the budget of processed phytodetritus as well, in sites ranging from estuarine to deep-sea environments.

Chemical reaction rates increase with increasing temperatures, including microbially mediated reactions in marine sediments such as organic matter mineralisation (Westrich and Berner, 1988). Effects of temperature on short-term processing of phytodetritus have been studied by Moodley et al. (2005), where they found that a decrease in temperature slowed down respiration considerably. By decreasing the temperature from $16^{\circ} \mathrm{C}$ in situ to a temperature of $6^{\circ} \mathrm{C}$, the contribution of respiration decreased from 17 to $3 \%$ of the added algal carbon respectively. In our experiments the length of the lag time in the appearance of excess ${ }^{13} \mathrm{C}$ into the DIC pool showed a smooth transition from warm, shallow sediments where no delay was observed to a lag time of almost two days at the deepest and coldest station. The increase in lag time with increasing station depth, and concurrently decreasing temperatures (Table 1), might be explained by a decoupling in the temperature response between the different functional groups of bacteria taking part in the mineralisation process. One group is responsible for performing the initial hydrolysis of organic matter to DOC and another group the respiration of these compounds to $\mathrm{CO}_{2}$. Such a decoupling might result in an accumulation of low-molecular weight DOC at low temperatures (Weston and Joye, 2005).

Bottom water oxygen concentrations may have an effect on sediment organic matter $(\mathrm{OM})$ processing, but literature evidence is scattered and sometimes conflicting. Hartnett et al. (1998) and Hedges et al. (1999) have reported correlative evidence that oxygen exposure time determines the extent of $\mathrm{OM}$ processing. Experimental studies examining the effect of oxygen on OM degradation have shown it to be small when the material is fresh and larger when it is more refractory (Hulthe et al., 1998; Kristensen et al., 1995), but these experiments were not done with undisturbed sediment originating from naturally suboxic environments. In this study, the effect of oxygen on respiration was not as pronounced as the effects of temperature, but was apparent at the $300 \mathrm{~m}$ station where oxygen levels were so low that virtually no macrofauna could exist. An unexpected decrease in oxygen levels at the $140 \mathrm{~m}$ station (Table 1), from $92 \mu \mathrm{M}$ in the pre-monsoon cruise to $5 \mu \mathrm{M}$ in the post-monsoon cruise, might have caused the respiration to decrease. However, not to the same level as at the $300 \mathrm{~m}$ station, which would be expected if the only factor determining respiration factor was oxygen. Concurrent with the decrease in oxygen at the $140 \mathrm{~m}$ station was also a decrease in temperature, which probably had a similar effect as the change in oxygen on the respiration.

\section{Conclusions}

Between 20 and $100 \%$ of the added algal carbon was left unprocessed in the sediment, mainly at the surface. Respiration accounted for the largest fraction of processed carbon, between 0 and $25 \%$, and was governed by both temperature and bottom-water oxygen levels The decrease in temperature from shallow to deeper situated sediments caused a progressively longer lag period in the respiration of the algal carbon. Macrofaunal influence was most pronounced at the lower part of the oxygen minimum zone $(940 \mathrm{~m})$, where high amounts of food overlaps with a sufficient concentration of oxygen. At this station macrofaunal uptake accounted for $11 \%$ of total phytodetritus processing.

Acknowledgements. We thank A. Gooday, K. Larkin and P. Lamont for sorting and picking foraminiferal and macrofaunal samples. We are also grateful to E. Breuer and O. Peppe for running the lander and megacorer. We acknowledge all the valuable support given by L. Moodley for both experimental planning and discussion about results.

This research was supported by Netherlands Organization for Scientific Research $(812.02 .004 ; 833.02 .2002)$ and carried out onboard RRS Charles Darwin financed by UK Natural Environment Research Council. This is publication number 4130 from the Netherlands Institute of Ecology (NIOO-KNAW).

Edited by: S. W. A. Naqvi

\section{References}

Aller, R. C.: The sedimentary Mn cycle in Long-Island Sound its role as intermediate oxidant and the influence of bioturbation, $\mathrm{O}_{2}$, and $\mathrm{C}_{\mathrm{ORG}}$ flux on diagenetic reaction balances, J. Mar. Res., 52, 259-295, 1994.

Andersson, J. H., Wijsman, J. W. M., Herman, P. M. J., Middelburg, J. J., Soetaert, K., and Heip, C.: Respiration in the deep ocean, Geophys. Res. Lett., 31, L03304, doi:10.1029/2003GL018756, 2004.

Barnett, P. R. O., Watson, J., and Connelly, D.: A multiple corer for taking virtually undisturbed samples from shelf, bathyal and abyssal sediments, Oceanol. Acta, 7, 399-408, 1984.

Beaulieu, S. E.: Accumulation and fate of phytodetritus on the sea floor, Oceanogr. Mar. Biol., 40, 171-232, 2002.

Beaulieu, S. E.: Resuspension of phytodetritus from the sea floor: A laboratory flume study, Limnol. Oceanogr., 48, 1235-1244, 2003.

Blair, N. E., Levin, L. A., DeMaster, D. J., and Plaia, G.: The shortterm fate of fresh algal carbon in continental slope sediments, Limnol. Oceanogr., 41, 1208-1219, 1996.

Boschker, H. T. S. and Middelburg, J. J.: Stable isotopes and biomarkers in microbial ecology, FEMS Microb. Ecol., 40, 8595, 2002.

Boschker, H. T. S., de Brouwer, J. F. C., and Cappenberg, T. E.: The contribution of macrophyte-derived organic matter to microbial biomass in salt-marsh sediments: Stable carbon isotope analysis of microbial biomarkers, Limnol. Oceanogr., 44, 309-319, 1999. 
Buhring, S. I., Lampadariou, N., Moodley, L., Tselepides, A., and Witte, U.: Benthic microbial and whole-community responses to different amounts of ${ }^{13} \mathrm{C}$-enriched algae: In situ experiments in the deep Cretan Sea (Eastern Mediterranean), Limnol. Oceanogr., 51, 157-165, 2006.

Burdige, D. J.: Preservation of organic matter in marine sediments: Controls, mechanisms, and an imbalance in sediment organic carbon budgets?, Chem. Rev., 107, 467-485, 2007.

Cowie, G. L., Calvert, S. E., Pedersen, T. F., Schulz, H., and von Rad, U.: Organic content and preservational controls in surficial shelf and slope sediments from the Arabian Sea (Pakistan margin), Mar. Geol., 161, 23-38, 1999.

Devol, A. H. and Hartnett, H. E.: Role of the oxygen-deficient zone in transfer of organic carbon to the deep ocean, Limnol. Oceanogr., 46, 1684-1690, 2001.

Francois, R., Honjo, S., Krishfield, R., and Manganini, S.: Factors controlling the flux of organic carbon to the bathypelagic zone of the ocean, Global Biogeochem. Cy., 16, 1087, doi:10.1029/2001GB001722, 2002.

Glud, R. N., Gundersen, J. K., Jorgensen, B. B., Revsbech, N. P., and Schulz, H. D.: Diffusive and total oxygen-uptake of deep-sea sediments in the Eastern South-Atlantic ocean - in-situ and laboratory measurements, Deep-Sea Res. I, 41, 1767-1788, 1994.

Glud, R. N., Gundersen, J. K., Revsbech, N. P., Jorgensen, B. B., and Huttel, M.: Calibration and performance of the stirred flux chamber from the benthic lander Elinor, Deep-Sea Res. I, 42, 1029-1042, 1995.

Gooday, A. J.: Biological responses to seasonally varying fluxes of organic matter to the ocean floor: A review, J. Oceanography, 58, 305-332, 2002.

Haake, B., Ittekkot, V., Rixen, T., Ramaswamy, V., Nair, R. R., and Curry, W. B.: Seasonality and interannual variability of particle fluxes to the deep Arabian sea, Deep-Sea Res. I, 40, 1323-1344, 1993.

Hartnett, H. E., Keil, R. G., Hedges, J. I., and Devol, A. H.: Influence of oxygen exposure time on organic carbon preservation in continental margin sediments, Nature, 391, 572-574, 1998.

Hedges, J. I., S, H. F., Devol, A. H., Hartnett, H. E., Tsamakis, E., and Keil, R. G.: Sedimentary organic matter preservation: A test for selective degradation under oxic conditions, Am. J. Sci., 299, 529-555, 1999.

Helly, J. J. and Levin, L. A.: Global distribution of naturally occurring marine hypoxia on continental margins, Deep-Sea Res. I, 51, 1159-1168, 2004.

Hulthe, G., Hulth, S., and Hall, P. O. J.: Effect of oxygen on degradation rate of refractory and labile organic matter in contintental margin sediments, Geochim. Cosmochim. Acta, 62, 1319-1328, 1998.

Kamp, A. and Witte, U.: Processing of C-13-labelled phytoplankton in a fine-grained sandy-shelf sediment (North Sea): relative importance of different macrofauna species, Mar. Ecol. Prog. Ser., 297, 61-70, 2005.

Kawamiya, M. and Oschlies, A.: An eddy-permitting, coupled ecosystem-circulation model of the Arabian Sea: comparison with observations, J. Mar. Syst., 38, 221-257, 2003.

Keeling, R. F. and Garcia, H. E.: The change in oceanic $\mathrm{O}_{2}$ inventory associated with recent global warming, Proc. Nat. Acad. Sci. USA, 99, 7848-7853, 2002.
Kriest, I. and Evans, G. T.: Representing phytoplankton aggregates in biogeochemical models, Deep-Sea Res. I, 46, 1841-1859, 1999.

Kristensen, E., Ahmed, S. I., and Devol, A. H.: Aerobic and anaerobic decomposition of organic matter in marine sediment: Which is fastest?, Limnol. Oceanogr., 40, 1430-1437, 1995.

Levin, L., Blair, N., DeMaster, D., Plaia, G., Fornes, W., Martin, C., and Thomas, C.: Rapid subduction of organic matter by maldanid polychaetes on the North Carolina slope, J. Mar. Res., 55, 596-611, 1997.

Middelburg, J. J., Barranguet, C., Boschker, H. T. S., Herman, P. M. J., Moens, T., and Heip, C. H. R.: The fate of intertidal microphytobenthos carbon: An in situ ${ }^{13} \mathrm{C}$-labeling study, Limnol. Oceanogr., 45, 1224-1234, 2000.

Moodley, L., Boschker, H. T. S., Middelburg, J. J., Pel, R., Herman, P. M. J., de Deckere, E., and Heip, C. H. R.: Ecological significance of benthic foraminifera: ${ }^{13} \mathrm{C}$ labelling experiments, Mar. Ecol. Prog. Ser., 202, 289-295, 2000.

Moodley, L., Middelburg, J. J., Boschker, H. T. S., Duineveld, G. C. A., Pel, R., Herman, P. M. J., and Heip, C. H. R.: Bacteria and Foraminifera: key players in a short-term deep-sea benthic response to phytodetritus, Mar. Ecol. Prog. Ser., 236, 23-29, 2002.

Moodley, L., Middelburg, J. J., Soetaert, K., Boschker, H. T. S., Herman, P. M. J., and Heip, C. H. R.: Similar rapid response to phytodetritus deposition in shallow and deep-sea sediments, J. Mar. Res., 63, 457-469, 2005.

Naqvi, S. W. A.: Some aspects of the oxygen-deficient conditions and denitrification in the Arabian Sea, J. Mar. Res., 49, 1049$1072,1987$.

Naqvi, S. W. A., Jayakumar, D., Narvekar, P., Naik, H., Sarma, V. V. S. S., D'Souza, W., Joseph, S., and George, M. D.: Increased marine production of $\mathrm{N}_{2} \mathrm{O}$ due to intensifying anoxia on the Indian continental shelf, Nature, 408, 346-349, 2000.

Naqvi, S. W. A., Sarma, V. V. S. S., and Jayakumar, D. A.: Carbon cycling in the northern Arabian Sea: Significance of salps, 226, 35-44, 2002.

Sayles, F. L., Martin, W. R., and Deuser, W. G.: Response of benthic oxygen-demand to particulate organic-carbon supply in the deepsea near Bermuda, Nature, 371, 686-689, 1994.

Smith, K. L.: Benthic Boundary-Layer Communities and Carbon Cycling at Abyssal Depths in the Central North Pacific, Limnol. Oceanogr., 37, 1034-1056, 1992.

Soetaert, K., Herman, P. M. J., and Middelburg, J. J.: Dynamic response of deep-sea sediments to seasonal variations: A model, Limnol. Oceanogr., 41, 1651-1668, 1996.

Warren, B. A.: Context of the suboxic layer in the Arabian Sea, Proc. Indian Acad. Sci., Earth planet. sci., 103, 301-314, 1994.

Weston, N. B. and Joye, S. B.: Temperature-driven decoupling of key phases of organic matter degradation in marine sediments, Proc. Nat. Acad. Sci. USA, 102, 17 036-17 040, 2005.

Westrich, J. T. and Berner, R. A.: The effect of temperature on rates of sulfate reduction in marine sediments, Geomicrob. J., 6, 99117, 1988.

Wiggert, J. D., Hood, R. R., Banse, K., and Kindle, J. C.: Monsoondriven biogeochemical processes in the Arabian Sea, Prog. Oceanogr., 65, 176-213, 2005.

Witte, U., Aberle, N., Sand, M., and Wenzhofer, F.: Rapid response of a deep-sea benthic community to POM enrichment: an in situ experimental study, Mar. Ecol. Prog. Ser., 251, 27-36, 2003 a. 
Witte, U., Wenzhofer, F., Sommer, S., Boetius, A., Heinz, P., Aberle, N., Sand, M., Cremer, A., Abraham, W. R., Jorgensen, B. B., and Pfannkuche, O.: In situ experimental evidence of the fate of a phytodetritus pulse at the abyssal sea floor, Nature, 424 , 763-766, 2003b.
Woulds, C., Cowie, G. L., Levin, L. A., Andersson, J. H., Middelburg, J. J., Vandewiele, S., Lamont, P. A., Larkin, K. E., Gooday, A. J., Schumacher, S., Whitcraft, C., Jeffreys, R., and Schwartz, M.: Oxygen as a control on sea floor faunal communities and their roles in sedimentary carbon cycling, Limnol. Oceanogr., 52, 1698-1709, 2007. 